CLINICAL STUDY

\title{
Plasma adrenomedullin level is related to a single nucleotide polymorphism in the adrenomedullin gene
}

\author{
Bernard M Y Cheung ${ }^{1,2}$, Kwok Leung Ong ${ }^{1}$, Annette W K Tso ${ }^{1,2}$, Raymond Y H Leung ${ }^{1}$, Stacey S Cherny ${ }^{3,4}$, \\ Pak Chung Sham ${ }^{3,4,5}$, Tai Hing Lam ${ }^{6}$, Karen S L Lam ${ }^{1,2}$ and on behalf of the Investigators of the Hong Kong \\ Cardiovascular Risk Factor Prevalence Study \\ ${ }^{1}$ Department of Medicine, ${ }^{2}$ Research Centre of Heart, Brain, Hormone and Healthy Aging, ${ }^{3}$ Department of Psychiatry, ${ }^{4}$ The State Key Laboratory of Brain \\ and Cognitive Sciences, ${ }^{5}$ Genome Research Centre and ${ }^{6}$ Department of Community Medicine, School of Public Health, University of Hong Kong, Hong Kong, \\ People's Republic of China
}

(Correspondence should be addressed to B M Y Cheung at Department of Medicine, Queen Mary Hospital, University of Hong Kong; Email: mycheung@hku.hk)

\begin{abstract}
Objective: Adrenomedullin $(A D M)$ plays an important role in inflammation and is a marker of future cardiovascular events. We studied common single nucleotide polymorphisms (SNPs) in the gene encoding ADM and their relationship with the plasma levels of ADM and other inflammatory markers. Design and methods: Plasma ADM, interleukin 6 (IL6), fibrinogen, and C-reactive protein (CRP) were measured in 476 subjects from the population-based Hong Kong Cardiovascular Risk Factor Prevalence Study-2. Four tag SNPs in ADM were genotyped.

Results: Plasma ADM level increased with decreasing plasma IL6 level $(\beta=-0.116, P=0.014)$. Plasma ADM level was not related to plasma levels of CRP and fibrinogen, and other clinical characteristics, except age $(P=0.049)$. The four SNPs, rs3814700, rs11042725, rs34354539, and rs4910118, had minor allele frequencies of 31.1, 28.7, 33.8, and 23.4\% respectively. Carriers of the minor allele of rs4910118 had a mean plasma ADM level that was $10.5 \%(95 \%$ confidential interval: $2.5-17.8 \%)$ lower than the non-carriers $(\beta=-0.115, P=0.011)$. Haplotype analysis revealed a similar significant association with plasma ADM $(P=0.040)$. In multivariate analysis, the presence of the minor allele of rs4910118, but not plasma IL6, was independently associated with plasma ADM $(P=0.010)$.

Conclusion: Plasma ADM correlates with plasma IL6 level, consistent with its role in inflammation. It is related to an SNP common in Chinese, independent of other covariates. ADM genotype should be included in future studies of cardiovascular risk prediction.
\end{abstract}

European Journal of Endocrinology 165 571-577

\section{Introduction}

Adrenomedullin (ADM) is a vasodilatory peptide that acts directly via cAMP and indirectly via endothelial nitric oxide (1-3). The gene ADM, located on chromosome 11p15.4, encodes prepro-ADM that is then processed to the circulating form of $\mathrm{ADM}$ by posttranslational modification (1-3). ADM is an adipokine (3) and is expressed in many different tissues, including adipose tissue, adrenal medulla, lung, heart, and kidney (1-4). Its plasma level is elevated in obesity (5-7), hypertension $(8,9)$, renal failure $(8,9)$, type 2 diabetes (10-12), and congestive heart failure $(8,13)$. ADM also plays an important regulatory role in both acute and chronic inflammation (14-16). Recent studies have suggested that high plasma levels of ADM or pro-ADM are predictive of the progression of chronic kidney disease (17), mortality after septic shock (18), and cardiovascular diseases or events (19-21).
Given the potential role of ADM as a biomarker of cardiovascular diseases or events, it is essential to investigate the factors that may affect plasma ADM. However, there are no systematic studies on the relationship between genetic variants in $A D M$ and plasma ADM. Besides genetic factors, there are other factors that may affect plasma ADM. Plasma ADM may be related to plasma interleukin 6 (IL6) due to the presence of a nuclear factor for IL6 expression (NF-IL6) binding site in the $A D M$ gene promoter (22). As IL6 regulates the hepatic production of $\mathrm{C}$-reactive protein (CRP) and fibrinogen (23), plasma ADM may also be related to these acute phase proteins. However, the relationship between plasma ADM and these inflammatory biomarkers of cardiovascular risk is not well established. Therefore, we investigated the association of plasma ADM with common single nucleotide polymorphisms (SNPs) in ADM and plasma levels of IL6, CRP, and fibrinogen in Chinese (Hong Kong). 


\section{Materials and methods}

\section{Subjects}

Plasma ADM was measured in 476 subjects randomly selected from the sub-cohort of 1375 subjects in the population-based Hong Kong Cardiovascular Risk Factor Prevalence Study-2 (24). There was no significant difference in age, sex, and body mass index (BMI) between the subjects with and without measurement of plasma ADM (all $P>0.05$ ). All subjects gave written informed consent. The study protocol was approved by the Ethics Committee of the University of Hong Kong. Details on the study protocols and the measurement methods of clinical parameters such as BMI, blood pressure, fasting glucose, insulin, homeostasis model assessment of insulin resistance index (HOMA-IR), high-density lipoprotein (HDL) cholesterol, low-density lipoprotein (LDL) cholesterol, and adiponectin have been described previously (24-29). Regular drinking was defined as alcohol drinking at least once a week. Regular exercise was defined as performing exercise for $\geq 30 \mathrm{~min}$ at least once a week in the past month. Smoking was defined as smoking cigarettes currently.

\section{SNP selection and genotyping}

Four SNPs (rs3814700, rs11042725, rs34354539, and rs4910118) in ADM were selected for genotyping as described previously (30). Briefly, the two SNPs, rs3814700 and rs4910118, captured all of the four SNPs (rs4641466, rs4399321, rs3814700, and rs4910118) from $5 \mathrm{~kb}$ region upstream to $2 \mathrm{~kb}$ downstream of the gene in the HapMap Han Chinese (phase II data, release 24) with $r^{2} \geq 0.8$ and minor allele frequency (MAF) $\geq 5 \%$. The other two SNPs, rs1 1042725 and rs34354539, were selected from the NCBI database based on their reported MAFs $\geq 5 \%$ in Asians. The SNP rs34354539 is an insertion-deletion variant and the minor allele is indicated by ' - '. Genotyping was performed using the MassARRAY system (Sequenom, San Diego, CA, USA) with the iPLEX assay in the Genome Research Centre, University of Hong Kong.

\section{Measurement of plasma ADM and other biomarkers}

Plasma sample was first extracted and then measured by RIA as described previously with slight modification $(8,16,31)$. Briefly, plasma immunoreactivity of ADM was determined by commercially available RIA kits from Peninsula Laboratories (Belmont, CA, USA) in 235 subjects and Phoenix Pharmaceuticals (Burlingame, CA, USA) in 241 subjects according to the manufacturers' instructions. One milliliter of plasma was acidified with $0.25 \mathrm{ml}$ of $2 \mathrm{~mol} / \mathrm{l}$ hydrochloric acid and centrifuged at $3500 \boldsymbol{g}$ for $20 \mathrm{~min}$. Supernatants were loaded onto Sep-Pak C18 cartridges (Waters Associates, Milford, MA, USA) that were activated with 100\% methyl alcohol and double-distilled deionized water. Cartridges were subsequently washed twice with $3 \mathrm{ml}$ $0.1 \%$ trifluoroacetic acid (TFA) and eluted with $3 \mathrm{ml}$ $60 \%$ acetonitrite in $0.1 \%$ TFA. The eluates were then dried under vacuum overnight and resuspended in $250 \mu \mathrm{l}$ RIA buffer. Standard ADM or assay sample $(100 \mu \mathrm{l})$ was incubated overnight at $4{ }^{\circ} \mathrm{C}$ with $100 \mu \mathrm{l}$ of rabbit anti-ADM antiserum. ${ }^{125} \mathrm{I}$-ADM tracer $(100 \mu \mathrm{l})$ was added to each tube and incubated for another $24 \mathrm{~h}$. Using a goat anti-rabbit antiserum, antibody-bound ADM was precipitated and the radioactivity was measured in a gamma counter. A standard curve was constructed using serial dilutions of freshly reconstituted synthetic human ADM. The plasma level of ADM was expressed as picomoles per liter. Among 235 subjects with plasma ADM measured by RIA kits from Peninsula Laboratories, 15 had the measured level below the limit of detection (i.e. $<4.10 \mathrm{pmol} / \mathrm{l}$ ) and a level equal to the limit of detection divided by the square root of two was imputed (32). Plasma fibrinogen was measured using a Cobas Fibro instrument (Roche Diagnostics) as described previously (33). Plasma high-sensitivity CRP was measured with an in-house sandwich ELISA established in our laboratory as described previously $(34,35)$. Plasma IL6 was measured by commercially available high-sensitivity ELISA kits (Bender MedSystems GmbH, Vienna, Austria). The IL6 ELISA method had a sensitivity of $0.02 \mathrm{ng} / \mathrm{l}$, intra-assay coefficient of variation $(\mathrm{CV})$ of $6.9 \%$, and inter-assay $\mathrm{CV}$ of $8.0 \%$.

\section{Statistical analysis}

Statistical analysis was performed using SPSS 15.0 for Windows (SPSS, Inc., Chicago, IL, USA). Data were presented as mean \pm s.D. Variables with a skewed distribution were log-transformed before analysis and were presented as geometric mean $(95 \%$ confidential interval (CI)). Haploview version 4.1 (Cambridge, MA, USA) was used to assess linkage disequilibrium (LD) (36). Subjects homozygous for the minor allele were grouped with heterozygotes for comparison with those homozygous for the major allele to increase the sample size for comparison, assuming a dominant model of inheritance for the minor allele. Correction for multiple testing of four SNPs was performed using Bonferroni's method. Correction for testing of multiple phenotypes was not performed as the phenotypes tested were closely related to each other. Haplotype analysis was performed using the program PLINK (version 1.0.7) (37). Only haplotypes with frequency $>5 \%$ were tested. An omnibus test was first performed to assess the global $P$ value of the overall variation at the locus. The effect of each of the specific haplotypes was then estimated by comparing with all other haplotypes combined. To assess the independent association of plasma ADM with 
Table 1 Subject characteristics according to tertiles of plasma adrenomedullin. Data are expressed as mean \pm S.D. unless otherwise stated.

\begin{tabular}{|c|c|c|c|c|}
\hline Characteristics & $\begin{array}{l}\text { Tertile } 1 \\
(<10.7 \mathrm{pmol} / \mathrm{l})\end{array}$ & $\begin{array}{l}\text { Tertile } 2 \\
(10.7-14.1 \mathrm{pmol} / \mathrm{l})\end{array}$ & $\begin{array}{l}\text { Tertile } 3 \\
(\geq 14.3 \mathrm{pmol} / \mathrm{l})\end{array}$ & $P$ for trend ${ }^{*}$ \\
\hline$n$ & 160 & 155 & 161 & - \\
\hline Age (years) & $52.2 \pm 11.0$ & $50.0 \pm 10.7$ & $50.6 \pm 10.5$ & 0.049 \\
\hline Women (\%) & 50.0 & 51.6 & 49.7 & 0.941 \\
\hline BMI $\left(\mathrm{kg} / \mathrm{m}^{2}\right)$ & $24.1 \pm 3.3$ & $23.2 \pm 3.2$ & $24.2 \pm 3.9$ & 0.649 \\
\hline Waist circumference $(\mathrm{cm})$ & $79.8 \pm 9.5$ & $78.5 \pm 9.8$ & $80.8 \pm 10.9$ & 0.273 \\
\hline $\mathrm{SBP}(\mathrm{mmHg})$ & $124 . \overline{6} \pm 17.8$ & $120 . \overline{4} \pm 17.4$ & $123 . \overline{1} \pm 18.9$ & 0.739 \\
\hline $\mathrm{DBP}(\mathrm{mmHg})$ & $77.8 \pm 10.5$ & $75.5 \pm 9.6$ & $76.9 \pm 10.8$ & 0.742 \\
\hline Triglycerides $\left(\mathrm{mmol} / \mathrm{l}^{\mathrm{a}}\right.$ & $1.24(1.14-1.36)$ & $1.19(1.10-1.29)$ & $1.13(1.05-1.21)$ & 0.076 \\
\hline HDL cholesterol (mmol/l) & $1.40 \pm 0.42$ & $1.37 \pm 0.34$ & $1.35 \pm 0.39$ & 0.487 \\
\hline LDL cholesterol (mmol/l) & $3.23 \pm 0.87$ & $3.31 \pm 0.85$ & $3.23 \pm 0.81$ & 0.675 \\
\hline Fasting glucose $(\mathrm{mmol} /)^{\mathrm{a}}$ & $5.30(5.14-5.47)$ & $5.17(5.02-5.33)$ & $5.25(5.11-5.41)$ & 0.601 \\
\hline Fasting insulin $\left(\mathrm{mlU} / \mathrm{I}^{\mathrm{a}}\right.$ & 7.49 (6.89-8.15) & $7.12(6.49-7.81)$ & $7.54(6.90-8.25)$ & 0.853 \\
\hline HOMA-IR ${ }^{\mathrm{a}}$ & $1.77(1.60-1.95)$ & $1.64(1.48-1.82)$ & $1.76(1.59-1.95)$ & 0.754 \\
\hline Adiponectin (mg/l) ${ }^{a}$ & $6.80(6.12-7.56)$ & $6.92(6.28-7.62)$ & $6.95(6.29-7.68)$ & 0.507 \\
\hline Fibrinogen $(\mathrm{g} / \mathrm{l})$ & $2.93 \pm 0.58$ & $2.89 \pm 0.51$ & $2.95 \pm 0.50$ & 0.462 \\
\hline $\operatorname{CRP}(\mathrm{mg} / \mathrm{l})^{\mathrm{a}}$ & $0.58(0.50-0.69)$ & $0.52(0.45-0.61)$ & $0.58(0.50-0.67)$ & 0.373 \\
\hline IL6 $\left(\mathrm{ng} / \mathrm{l}^{\mathrm{a}}\right.$ & $0.60(0.53-0.69)$ & $0.42(0.37-0.49)$ & $0.40(0.34-0.46)$ & 0.014 \\
\hline Current smoking (\%) & 16.9 & 21.3 & 18.6 & 0.468 \\
\hline Regular drinking (\%) & 9.6 & 12.6 & 9.0 & 0.830 \\
\hline Regular exercise (\%) & 32.2 & 26.5 & 29.2 & 0.530 \\
\hline
\end{tabular}

${ }^{\star} P$ values were adjusted for age and sex, except for age (adjusted for sex only) and sex (for age only).

${ }^{a}$ For variables with a skewed distribution, data are expressed as geometric mean $(95 \% \mathrm{Cl})$.

genetic variants and other plasma biomarkers, multiple linear regression analysis was used to adjust for age and sex in the initial model and then all other demographic and biochemical variables in the final adjustment model. For variables that were highly correlated, such as BMI and waist circumference, only one was entered into the model. As plasma IL6 and ADM were logtransformed in the regression analysis, regression coefficients were converted to the percentage changes for easy interpretation.

\section{Results}

Table 1 shows the clinical characteristics of the subjects according to the tertiles of plasma ADM. There was a marginally significant trend of decreasing age with increasing tertiles of plasma $\operatorname{ADM}(\beta=-0.089$, $P=0.049)$. Plasma IL6 decreased significantly with increasing tertiles of plasma $\operatorname{ADM}(\beta=-0.116$, $P=0.014)$. The mean change in plasma IL6 per tertile of plasma ADM was $-11.9 \%(95 \% \mathrm{CI}$ : $-20.3,-2.6)$ after adjusting for age and sex. The association of plasma ADM tertiles with plasma IL6 remained significant after further adjusting for BMI, HOMA-IR, HDL cholesterol, triglycerides, plasma adiponectin, CRP, fibrinogen, current smoking, regular drinking, and regular exercise $(\beta=-0.135$, mean \% change $(95 \% \mathrm{CI})$ per tertile of plasma $\mathrm{ADM}=-28.9(-43.9$, -9.9), $P=0.005)$. Plasma ADM did not correlate with other clinical characteristics or biomarkers, including plasma CRP and fibrinogen $(P>0.05)$.

The MAFs of the four SNPs, rs3814700, rs11042725, rs34354539, and rs4910118, were 31.1, 28.7, 33.8, and $23.4 \%$ respectively. None of these SNPs showed significant deviation from Hardy-Weinberg equilibrium $(P>0.05)$. The three SNPs, rs3814700, rs11042725, and rs34354539, showed moderate-to-high pairwise LD with each other $\left(r^{2}=0.747-0.891\right)$. As shown in Fig. 1, the SNP rs4910118 was significantly associated with plasma $\operatorname{ADM}(\beta=-0.115, P=0.011)$. The presence of the minor $\mathrm{T}$ allele of rs4910118 was associated with a $-10.5 \%(95 \%$ CI: $-17.8,-2.5)$ change in plasma ADM after adjusting for age and sex. In multivariate analysis, the presence of the minor allele of rs4910118, but not plasma IL6, was independently associated with plasma ADM $(\%$ change $(95 \% \mathrm{CI})=-11.0(-18.5$, $-2.8), P=0.010$; Table 2).

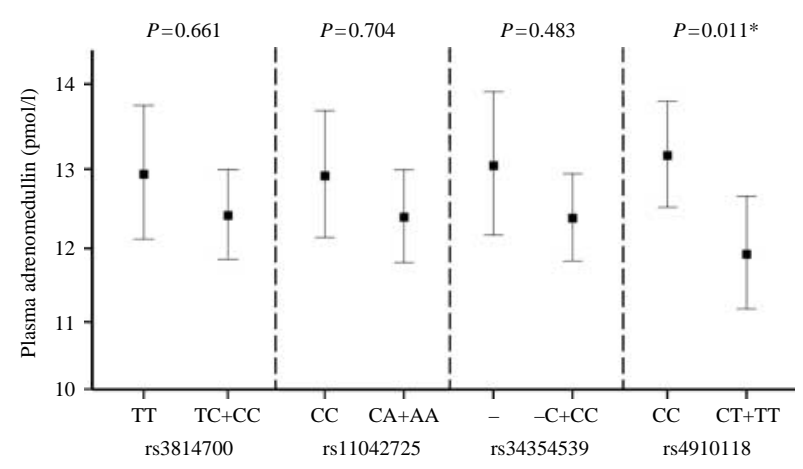

Figure 1 Association of SNPs with plasma adrenomedullin. The error bar shows the $95 \% \mathrm{Cl}$ of the mean. The SNP rs34354539 is an insertion-deletion variant and the minor allele is indicated by '-'. $P$ values were calculated using the log-transformed levels after adjusting for age and sex. ${ }^{*} P$ value can pass multiple testing corrections $(P<0.0125)$. 
Table 2 Multivariate analysis for plasma ADM (log transformed).

\begin{tabular}{lcc}
\hline Genotype & $\boldsymbol{\beta}$ & $\boldsymbol{P}$ \\
\hline CT/TT genotype of rs4910118 & -0.122 & 0.010 \\
Age (years) & -0.072 & 0.133 \\
IL6 (ng/l) & -0.083 & 0.093 \\
\hline
\end{tabular}

${ }^{\mathrm{a}}$ For variables with a skewed distribution, data are log-transformed before analysis.

When haplotypes were constructed using rs3814700, rs11042725, rs34354539, and rs4910118, there were three haplotypes with frequency $>5 \%$, namely TC-C, CACC, and TC-T respectively (Table 3). Haplotype analysis revealed a similar significant association with plasma ADM (overall $P=0.040$ ), in which haplotype TC-C was associated with higher level and haplotype TC-T was associated with lower level compared with all other haplotypes combined (Table 3). As there was a significant difference in plasma ADM between these two haplotypes, which differed only at the rs4910118 position, the association of rs4910118 with plasma ADM was independent of the haplotypic background $(P=0.011)$. Therefore, the overall haplotype association with plasma ADM was mainly contributed by rs4910118, but not other SNPs. Carriers of the minor allele of rs4910118 tended to have more regular exercise than the non-carriers (35.3 vs $25.4 \%$, $P=0.018$ after adjusting for age and sex). The SNP rs4910118 was not associated with other clinical characteristics.

\section{Discussion}

There have only been a few genetic association studies on ADM. These previous studies showed significant associations of SNPs or a microsatellite marker of cytosine-adenine (CA) repeat located at the $3^{\prime}$-end of $A D M$ with essential hypertension, renal diseases, and dysglycemia $(30,38-42)$. However, most of these studies have not examined the association of these genetic variants with plasma $A D M$. Only two studies have investigated the effect of the microsatellite marker of CA repeat on plasma ADM, but the results of both the studies were negative $(39,40)$. Our study demonstrated for the first time that the common SNP rs4910118, with a MAF of $23.4 \%$, was associated with plasma ADM in Chinese (Hong Kong).
Genetic variants such as rs11042725 have been reported to have functional effect on the promoter function of $A D M$ (43). The SNP rs4910118 is located at $762 \mathrm{bp}$ downstream of the $3^{\prime}$-end of ADM. Using the program ssSNPer (44), only one SNP (rs2923126) in the surrounding $1 \mathrm{Mbp}$ region was found to be in high LD $\left(r^{2}=0.925\right)$ with $r$ 4910118 in the HapMap Han Chinese. The SNP rs2923126 is located in an intergenic region and the nearest gene is $A D M$ (about $14.1 \mathrm{~kb}$ downstream from the $3^{\prime}$-end of $A D M$ gene). Therefore, the causative variant should be located in the ADM gene region, although the possibility of a distant causative variant, which has not been genotyped in the HapMap project, cannot be excluded.

As ADM plays a role in inflammation, its plasma level may be associated with other inflammatory biomarkers such as IL6, CRP, and fibrinogen. In a study of patients with early rheumatoid arthritis, plasma ADM was associated with plasma IL6, but not with other inflammatory biomarkers such as CRP and tumor necrosis factor $\alpha(\mathrm{TNF} \alpha)$ (45). In another study on subjects with two or more cardiovascular risk factors or diseases, plasma CRP increased with increasing tertiles of plasma ADM (21). In our study of subjects drawn from the general population, a significant correlation of plasma ADM was found with IL6, but not with other biomarkers. This finding is consistent with our previous reports, showing that ADM possesses both pro-inflammatory and anti-inflammatory properties, interacts with cytokines during inflammation, and plays an important role in both initiation and propagation of inflammatory response $(14,15,46)$. For example, ADM expression is increased by inflammatory stimuli such as lipopolysaccharide (LPS), whereas it can also increase the secretion of cytokines such as IL1 $\beta$ and IL6, but reduce LPS-induced TNF $\alpha$ secretion (14). Interestingly, ADM can reduce LPS-induced IL6 secretion from murine macrophages (47) and synoviocytes from patients with rheumatoid arthritis (48). Therefore, the action of ADM on IL6 production may differ according to cell types or conditions. The promoter region in human $A D M$ contains an NF-IL6 binding site, which regulates the basal expression of ADM (22). The induction of NF-IL6 by LPS, IL1, IL6, and $\mathrm{TNF} \alpha$ may explain the upregulation of $A D M$ gene expression in infectious or inflammatory conditions $(2,15,22,46)$. Nevertheless, in our study, the association of the SNP rs4910118 with plasma ADM was

Table 3 Association of haplotypes with plasma ADM. Data were adjusted for age and sex.

\begin{tabular}{|c|c|c|c|c|c|c|c|c|}
\hline Haplotype & rs3814700 & rs11042725 & rs34354539 ${ }^{a}$ & rs4910118 & Frequency & $\%$ change $(95 \% \mathrm{Cl})^{\mathrm{b}}$ & $\boldsymbol{P}$ & Overall $\boldsymbol{P}$ \\
\hline 1 & $\mathrm{~T}$ & $\mathrm{C}$ & - & $\mathrm{C}$ & 0.428 & $6.9(0.6,13.7)$ & 0.033 & 0.040 \\
\hline 2 & $\mathrm{C}$ & $A$ & $\mathrm{C}$ & $\mathrm{C}$ & 0.274 & $0.6(-6.2,7.9)$ & 0.861 & \\
\hline 3 & $\mathrm{~T}$ & $\mathrm{C}$ & - & $\mathrm{T}$ & 0.217 & $-8.4(-14.8,-1.6)$ & 0.018 & \\
\hline
\end{tabular}

aThe SNP rs34354539 is an insertion-deletion variant and the minor allele is indicated by '-'.

${ }^{\mathrm{b}}$ Compared with all other haplotypes combined. 
independent of plasma IL6 and conventional cardiovascular risk factors.

ADM has been suggested as a novel target for drug discovery (49). It has many diverse physiological functions, including neurotransmission, cardiovascular physiology, bronchodilation and pulmonary action, renal action, hormone regulation, electrolyte balance, reproductive physiology, growth regulation, and antimicrobial activity (49). Its plasma level is raised in various diseases, such as hypertension, diabetes, myocardial infarction, heart failure, renal failure, systemic lupus erythematosus, rheumatoid arthritis, and systemic sclerosis $(8-13,16,31,44,50)$. The expression of ADM has also been observed in many tumor cell lines and malignant tissues (49). Recent clinical studies have suggested ADM as a marker of chronic kidney disease and cardiovascular events. For example, elevated plasma level of the midregional fragment of pro-ADM (MR-proADM) was predictive of the progression of chronic kidney disease in a 7-year prospective study of 177 non-diabetic subjects (17). In a study of 99 patients with septic shock, elevated plasma MR-proADM level also predicted the 28-day mortality (18). In a study of 983 patients with acute myocardial infarction (AMI), plasma MR-proADM level was predictive of death or heart failure, especially in subjects with elevated plasma level of N-terminal pro-B-type natriuretic peptide, a well-studied prognostic marker of death and heart failure after AMI (19). Moreover, plasma MR-proADM level could also predict incident cardiovascular and coronary events in a 12.8-year prospective study of 5067 subjects without cardiovascular disease (20). In a Japanese prospective study of 121 patients at high risk of cardiovascular diseases, plasma ADM, but not CRP and adiponectin, predicted future cardiovascular events after a mean follow-up of 3.5 years (21). Therefore, our identification of a common genetic variant influencing plasma ADM level may help to refine the relationship between plasma ADM level and future adverse events. ADM genotype should be determined in future studies of the prediction of cardiovascular risk using plasma ADM levels. Moreover, as genetic variants are less likely to be confounded by environmental factors, the SNP rs4910118, which is associated with plasma ADM, could be used as an instrumental variable in future studies to assess the causal role of ADM in different diseases using Mendelian randomization (51).

In conclusion, plasma ADM is influenced by the SNP rs4910118 in ADM and correlates with plasma IL6 in Hong Kong Chinese. Further studies are needed to investigate how this SNP can affect plasma ADM.

\section{Declaration of interest}

The authors declare that there is no conflict of interest that could be perceived as prejudicing the impartiality of the research reported.

\section{Funding}

This study was funded by Hong Kong Research Grants Council grants (HKU7229/01M and HKU7626/07M) and the Sun Chieh Yeh Heart Foundation.

\section{References}

1 Cheung BM, Li CY \& Wong LY. Adrenomedullin: its role in the cardiovascular system. Seminars in Vascular Medicine 20044 129-134. (doi:10.1055/s-2004-835370)

2 Ishimitsu T, Ono H, Minami J \& Matsuoka H. Pathophysiologic and therapeutic implications of adrenomedullin in cardiovascular disorders. Pharmacology and Therapeutics 2006111 909-927. (doi:10.1016/j.pharmthera.2006.02.004)

3 Li Y, Jiang C, Wang X, Zhang Y, Shibahara S \& Takahashi K. Adrenomedullin is a novel adipokine: adrenomedullin in adipocytes and adipose tissues. Peptides 200728 1129-1143. (doi:10. 1016/j.peptides.2007.03.005)

4 Nambu T, Arai H, Komatsu Y, Yasoda A, Moriyama K, Kanamoto N, Itoh H \& Nakao K. Expression of the adrenomedullin gene in adipose tissue. Regulatory Peptides 2005132 17-22. (doi:10.1016/j.regpep.2005.07.006)

5 Minami J, Nishikimi T, Ishimitsu T, Makino Y, Kawano Y, Takishita S, Kangawa K \& Matsuoka H. Effect of a hypocaloric diet on adrenomedullin and natriuretic peptides in obese patients with essential hypertension. Journal of Cardiovascular Pharmacology 200036 S83-S86. (doi:10.1097/00005344-20000000600018)

6 Kato J, Kitamura K, Uemura T, Kuwasako K, Kita T, Kangawa K \& Eto T. Plasma levels of adrenomedullin and atrial and brain natriuretic peptides in the general population: their relations to age and pulse pressure. Hypertension Research 200225 887-892. (doi:10.1291/hypres.25.887)

7 Kato J, Kitamura K \& Eto T. Plasma adrenomedullin level and development of hypertension. Journal of Human Hypertension 2006 20 566-570. (doi:10.1038/sj.jhh.1002033)

8 Cheung B \& Leung R. Elevated plasma levels of human adrenomedullin in cardiovascular, respiratory, hepatic and renal disorders. Clinical Science 199792 59-62.

9 Ishimitsu T, Nishikimi T, Saito Y, Kitamura K, Eto T, Kangawa K, Matsuo H, Omae T \& Matsuoka H. Plasma levels of adrenomedullin, a newly identified hypotensive peptide, in patients with hypertension and renal failure. Journal of Clinical Investigation 199494 2158-2161. (doi:10.1172/JCI117573)

10 Hayashi M, Shimosawa T, Isska M, Yamada S, Fujita R \& Fujita T. Plasma adrenomedullin in diabetes. Lancet $1997 \mathbf{3 5 0}$ 1449-1450. (doi:10.1016/S0140-6736(05)64211-0)

11 Martínez A, Elsasser TH, Bhathena SJ, Pío R, Buchanan TA, Macri CJ \& Cuttitta F. Is adrenomedullin a causal agent in some cases of type 2 diabetes? Peptides 199920 1471-1478. (doi:10. 1016/S0196-9781(99)00158-8)

12 Turk HM, Buyukberber S, Sevinc A, Ak G, Ates M, Sari R, Savli H \& Cigli A. Relationship between plasma adrenomedullin levels and metabolic control, risk factors, and diabetic microangiopathy in patients with type 2 diabetes. Diabetes Care 200023 864-867. (doi:10.2337/diacare.23.6.864a)

13 Jougasaki M, Wei CM, McKinley LJ \& Burnett JC Jr. Elevation of circulating and ventricular adrenomedullin in human congestive heart failure. Circulation 199592 286-289. (doi:10.1161/01. CIR.92.3.286)

14 Wong LY, Cheung BM, Li CY \& Tang F. Adrenomedullin is both proinflammatory and antiinflammatory: its effects on gene expression and secretion of cytokines and macrophage migration inhibitory factor in NR8383 macrophage cell line. Endocrinology 2005 146 1321-1327. (doi:10.1210/en.2004-1080)

15 Li YY, Wong YF, Cheung BM, Hwang IS, Kumana CR \& Tang F. Differential induction of adenomedullin, interleukins and tumour 
necrosis factor- $\alpha$ by lipoplysaccharide in rat tissues in vivo. Clinical and Experimental Pharmacology \& Physiology 200532 1110-1118. (doi:10.1111/j.1440-1681.2005.04307.x)

16 Mak A, Cheung BM, Mok CC, Leung R \& Lau CS. Adrenomedullin - a potential disease activity marker and suppressor of nephritis activity in systemic lupus erythematosus. Rheumatology 200645 1266-1272. (doi:10.1093/rheumatology/kel105)

17 Dieplinger B, Mueller T, Kollerits B, Struck J, Ritz E, von Eckardstein A, Haltmayer M, Kronenberg F \& MMKD Study Group . Pro-A-type natriuretic peptide and pro-adrenomedullin predict progression of chronic kidney disease: the MMKD Study. Kidney International 200975 408-414. (doi:10.1038/ ki.2008.560)

18 Guignant C, Voirin N, Venet F, Poitevin F, Malcus C, Bohé J, Lepape A \& Monneret G. Assessment of pro-vasopressin and proadrenomedullin as predictors of 28-day mortality in septic shock patients. Intensive Care Medicine 200935 1859-1867. (doi:10. 1007/s00134-009-1610-5)

19 Khan SQ, O’Brien RJ, Struck J, Quinn P, Morgenthaler N, Squire I, Davies J, Bergmann A \& Ng LL. Prognostic value of midregional pro-adrenomedullin in patients with acute myocardial infarction: the LAMP (Leicester Acute Myocardial Infarction Peptide) study. Journal of the American College of Cardiology 200749 1525-1532. (doi:10.1016/j.jacc.2006.12.038)

20 Melander O, Newton-Cheh C, Almgren P, Hedblad B, Berglund G, Engström G, Persson M, Smith JG, Magnusson M, Christensson A, Struck J, Morgenthaler NG, Bergmann A, Pencina MJ \& Wang TJ. Novel and conventional biomarkers for prediction of incident cardiovascular events in the community. Journal of the American Medical Association 2009302 49-57. (doi:10.1001/jama.2009.943)

21 Nishida H, Horio T, Suzuki Y, Iwashima Y, Kamide K, Kangawa K \& Kawano Y. Plasma adrenomedullin as an independent predictor of future cardiovascular events in high-risk patients: comparison with C-reactive protein and adiponectin. Peptides 2008 29 599-605. (doi:10.1016/j.peptides.2007.12.006)

22 Ishimitsu T, Miyata A, Matsuoka H \& Kangawa K. Transcriptional regulation of human adrenomedullin gene in vascular endothelial cells. Biochemical and Biophysical Research Communications 1998 243 463-470. (doi:10.1006/bbrc.1998.8110)

23 Castell JV, Gómez-Lechón MJ, David M, Andus T, Geiger T, Trullenque R, Fabra R \& Heinrich PC. Interleukin 6 is the major regulator of acute phase protein synthesis in adult human hepatocytes. FEBS Letters 1989242 237-239. (doi:10.1016/ 0014-5793(89)80476-4)

24 Jiang CQ, Liu B, Cheung BM, Lam TH, Lin JM, Li Jin Y, Yue XJ, Ong KL, Tam S, Wong KS, Tomlinson B, Lam KS \& Thomas GN. A single nucleotide polymorphism in APOA5 determines triglyceride levels in Hong Kong and Guangzhou Chinese. European Journal of Human Genetics 201018 1255-1260. (doi:10.1038/ ejhg.2010.93)

25 Cheung BM, Wat NM, Tso AW, Tam S, Thomas GN, Leung GM, Tse HF, Woo J, Janus ED, Lau CP, Lam TH \& Lam KS. Association between raised blood pressure and dysglycemia in Hong Kong Chinese. Diabetes Care 200831 1889-1891. (doi:10.2337/dc080405)

26 Cheung BM, Wat NM, Man YB, Tam S, Thomas GN, Leung GM, Cheng $\mathrm{CH}$, Woo J, Janus ED, Lau CP, Lam TH \& Lam KS. Development of diabetes in Chinese with the metabolic syndrome: a 6-year prospective study. Diabetes Care 200730 1430-1436. (doi:10.2337/dc06-1820)

27 Cheung BM, Wat NM, Man YB, Tam S, Cheng CH, Leung GM, Woo J, Janus ED, Lau CP, Lam TH \& Lam KS. Relationship between the metabolic syndrome and the development of hypertension in the Hong Kong Cardiovascular Risk Factor Prevalence Study-2 (CRISPS2). American Journal of Hypertension 200821 17-22. (doi:10.1038/ajh.2007.19)

28 Cheung BM, Wat NM, Tam S, Thomas GN, Leung GM, Cheng CH, Woo J, Janus ED, Lau CP, Lam TH \& Lam KS. Components of the metabolic syndrome predictive of its development: a 6-year longitudinal study in Hong Kong Chinese. Clinical Endocrinology 200868 730-737. (doi:10.1111/j.1365-2265.2007.03110.x)

29 Ong KL, Li M, Tso AW, Xu A, Cherny SS, Sham PC, Tse HF, Lam TH, Cheung BM, Lam KS \& Investigators of the Hong Kong Cardiovascular Risk Factor Prevalence Study . Association of genetic variants in the adiponectin gene with adiponectin level and hypertension in Hong Kong Chinese. European Journal of Endocrinology 2010163 251-257. (doi:10.1530/EJE-10-0251)

30 Ong KL, Tso AW, Leung RY, Cherny SS, Sham PC, Lam TH, Cheung BM \& Lam KS. A genetic variant in the gene encoding adrenomedullin predicts the development of dysglycemia over 6.4 years in Chinese. Clinica Chimica Acta 2011412 353-357. (doi:10.1016/j.cca.2010.11.007)

31 Mok MY, Cheung BM, Lo Y, Leung RY, Wong WS \& Lau CS. Elevated plasma adrenomedullin and vascular manifestations in patients with systemic sclerosis. Journal of Rheumatology $2007 \mathbf{3 4}$ 2224-2229.

32 Navas-Acien A, Silbergeld EK, Pastor-Barriuso R \& Guallar E. Arsenic exposure and prevalence of type 2 diabetes in US adults. Journal of the American Medical Association 2008300 814-822. (doi:10.1001/jama.300.7.814)

33 Ong KL, Leung RY, Babinska A, Salifu MO, Ehrlich YH, Kornecki E, Wong LY, Tso AW, Cherny SS, Sham PC, Lam TH, Lam KS \& Cheung BM. Elevated plasma level of soluble F11 receptor/ junctional adhesion molecule-A (F11R/JAM-A) in hypertension. American Journal of Hypertension 200922 500-505. (doi:10. 1038/ajh.2009.23)

$34 \mathrm{Xu}$ A, Tso AW, Cheung BM, Wang Y, Wat NM, Fong CH, Yeung DC, Janus ED, Sham PC \& Lam KS. Circulating adipocyte-fatty acid binding protein levels predict the development of the metabolic syndrome: a 5-year prospective study. Circulation 2007115 1537-1543. (doi:10.1161/CIRCULATIONAHA.106.647503)

35 Lui MM, Lam JC, Mak HK, Xu A, Ooi C, Lam DC, Mak JC, Khong PL \& Ip MS. C-reactive protein is associated with obstructive sleep apnea independent of visceral obesity. Chest 2009135 950-956. (doi:10.1378/chest.08-1798)

36 Barrett JC, Fry B, Maller J \& Daly MJ. Haploview: analysis and visualization of $\mathrm{LD}$ and haplotype maps. Bioinformatics 200521 263-265. (doi:10.1093/bioinformatics/bth457)

37 Purcell S, Neale B, Todd-Brown K, Thomas L, Ferreira MA, Bender D, Maller J, Sklar P, de Bakker PI, Daly MJ \& Sham PC. PLINK: a tool set for whole-genome association and populationbased linkage analyses. American Journal of Human Genetics 2007 81 559-575. (doi:10.1086/519795)

38 Ishimitsu T, Hosoya K, Tsukada K, Minami J, Futoh Y, Ono H, Ohrui M, Hino J, Kangawa K \& Matsuoka H. Microsatellite DNA polymorphism of human adrenomedullin gene in normotensive subjects and patients with essential hypertension. Hypertension $2001389-12$.

39 Ishimitsu T, Hosoya K, Tsukada K, Minami J, Ono H, Ohrui M, Hino J, Kangawa K \& Matsuoka H. Chromosomal sublocalization and microsatellite DNA polymorphism of human adrenomedullin gene. Peptides 200122 1739-1744. (doi:10.1016/S01969781(01)00531-9)

40 Ishimitsu T, Tsukada K, Minami J, Ono H, Ohrui M, Hino J, Kangawa K \& Matsuoka H. Microsatellite DNA polymorphism of human adrenomedullin gene in type 2 diabetic patients with renal failure. Kidney International 200363 2230-2235. (doi:10.1046/ j.1523-1755.2003.00020.x)

41 Kobayashi Y, Nakayama T, Sato N, Izumi Y, Kokubun S \& Soma M. Haplotype-based case-control study revealing an association between the adrenomedullin gene and proteinuria in subjects with essential hypertension. Hypertension Research 200528 229-236. (doi:10.1291/hypres.28.229)

42 Li Y, Staessen JA, Li LH, Gao PJ, Thijs L, Brand E, BrandHerrmann SM, Zhu DL \& Wang JG. Blood pressure and urinary sodium excretion in relation to the A-1984G adrenomedullin polymorphism in a Chinese population. Kidney International 2006 69 1153-1158. (doi:10.1038/sj.ki.5000213) 
43 Glubb DM, McHugh PC, Deng X, Joyce PR \& Kennedy MA. Association of a functional polymorphism in the adrenomedullin gene (ADM) with response to paroxetine. Pharmacogenomics Journal 201010 126-133. (doi:10.1038/tpj.2009.33)

44 Nyholt DR. ssSNPer: identifying statistically similar SNPs to aid interpretation of genetic association studies. Bioinformatics 2006 22 2960-2961. (doi:10.1093/bioinformatics/btl518)

45 Hamada H, Saisyo K, Sekimoto T \& Chosa E. Plasma adrenomedullin and proadrenomedullin $\mathrm{N}$-terminal 20 peptide in patients diagnosed as having early rheumatoid arthritis. Modern Rheumatology 2010 20 389-395. (doi:10.1007/s10165-010-0295-5)

46 Li YY, Cheung BM, Wong LY, Hwang IS, Kumana CR \& Tang F. Adrenomedullin gene expression and levels in the cardiovascular system after treatment with lipopolysaccharide. Neuropeptides 200539 73-80. (doi:10.1016/j.npep.2004.11.002)

47 Kubo A, Minamino N, Isumi Y, Katafuchi T, Kangawa K, Dohi K \& Matsuo H. Production of adrenomedullin in macrophage cell line and peritoneal macrophage. Journal of Biological Chemistry 1998 273 16730-16738. (doi:10.1074/jbc.273.27.16730)

48 Nanke Y, Kotake S, Yonemoto K, Saito S, Tomatsu T \& Kamatani N. Adrenomedullin in synovial fluids from patients with rheumatoid arthritis inhibits interleukin 6 production from synoviocytes. Annals of the Rheumatic Diseases 200362 82-83. (doi:10.1136/ard.62.1.82)

49 García MA, Martín-Santamaría S, de Pascual-Teresa B, Ramos A, Julián M \& Martínez A. Adrenomedullin: a new and promising target for drug discovery. Expert Opinion on Therapeutic Targets 200610 303-317. (doi:10.1517/14728222. 10.2.303)

50 Cheung BM, Lau CS, Leung RY, Tong KK \& Kumana CR. Plasma adrenomedullin level in systemic lupus erythematosus. Rheumatology 200939 804-805. (doi:10.1093/rheumatology/ 39.7.804)

51 Davey Smith G \& Ebrahim S. Mendelian randomization: can genetic epidemiology contribute to understanding environmental determinants of disease? International Journal of Epidemiology 2003 32 1-22. (doi:10.1093/ije/dyg070)

Received 9 June 2011

Revised version received 21 July 2011

Accepted 28 July 2011 